\title{
Journey to work travel outcomes from 'city of short distances' compact city planning in Tübingen, Germany
}

\author{
Iqbal Hamiduddin \\ Bartlett School of Planning, University College London (UCL) \\ Email: i.hamiduddin@ucl.ac.uk \\ Pre-publication version. Published in Planning Practice and Research, $23^{\text {rd }}$ October 2017: \\ http://dx.doi.org/10.1080/02697459.2017.1378980
}

\begin{abstract}
In the southern German city of Tübingen, a 'city of short distances' planning model has been applied to try to reduce the need to travel through the co-location of employment space with housing - a style of compact city planning reportedly influenced by Jane Jacobs' principles for urban vitality. However, until now the impact of this mixed land use model on work travel patterns has not been systematically researched. This paper reports on empirical research that has explored the implications of the model for employing organisations and employees, through qualitative key actor interviews and quantitative data obtained by surveys of employees in short distance neighbourhoods and those in two control neighbourhoods. The findings show that short distance planning appears to reduce work travel distances and encourage sustainable travel patterns of work travel, although the role of residential self- selection in producing these patterns remains unclear in this preliminary study.
\end{abstract}

\section{Introduction}

Over 25 years have now elapsed since the first assessment report of the Intergovernmental Panel on Climate Change (IPCC) declared with high certainty that:

emissions resulting from human activities are substantially increasing the atmospheric concentrations of the greenhouse gases carbon dioxide, methane, chlorofluorocarbons (CFCs) and nitrous oxide. These increases will enhance the greenhouse effect, resulting on average in an additional warming of the Earth's surface.

\section{Houghton et al (1990: xi)}

Over this period, the contribution of transport to global greenhouse gas emissions has increased substantially across most countries, and now account for approximately $14 \%$ of greenhouse emissions worldwide (Pachauri et al, 2014) and for a quarter of emissions in Europe and the United States (EPA, 2016; European Commission, 2016). Much of this increase can be attributed to an increase in personal mobility and particularly in a road transport sector which has become responsible for over two thirds of 
transport emissions in Europe (European Commission, 2016). Cheap energy production over the late twentieth and early twenty-first centuries has allowed lifestyles and livelihoods to become organised on the assumption of sustained levels of mobility, with lock-in to this high energy system physically created by a combination of low density urban sprawl, road infrastructure and the separation of land uses. Low urban density in particular has become a proxy for urban unsustainability over the course of the three decades since Newman and Kenworthy (1989) presented an inverse correlation between the urban density of cities across the world and gasoline consumption - a metric strongly influenced by road travel.

An ensuing debate has tended to focus on the mechanics of this apparent relationship between urban density and travel and attendant directions of causality. Crucial uncertainties remain over the extent to which urban density is, by itself, a sufficient ingredient for reducing automobile use and encouraging greater use of physical and public transport modes (Melia et al, 2011). Indeed, fundamental issues remain over the representation of urban density and the extent to which complexities in urban form are taken into account (Banister, 2005), the relative influence of built environment qualities and social factors such as politics and social attitudes over transport provision and travel behaviour (Mees 2010) and the viability of high density development in future policy (Neuman, 2005; Howley et al, 2009).

In Germany, the urban compaction discussion has tended to emphasise urban structure as a critical factor in creating sustainable travel patterns rather than density alone. Der Stadt der kurzen wegen - the 'city of short distances' - (or the shorthand kurze wege - short ways, which is often used) concept encapsulates this policy emphasis on creating urban structures that encourage public transport or non-motorised travel. By way of illustration, a 1989 meeting of the Council of German Cities urged municipal authorities to:

[adopt] a policy of short ways in urban planning, [to reduce] the distance between living, working, [...] so as to avoid motor vehicle traffic and at the same time increase the attractiveness of public transport, the bicycle and pedestrian usage.

Wegener, 1994: 9

Across cities of Southern Germany, planners created locally nuanced short distance planning neighbourhood quarters the short distances concept emphasises mixed primary land use frameworks in response to their specific geographical context. In Freiburg for example, retail planning forms a core aspect of the short distances concept across the city. In Tübingen's new neighbourhood quarters the short distances concept emphasies mixed primary land use functions through the co-location of residential and employment uses; the manifestation of 1 Jane Jacobs' core principle for urban vitality as set out in her 1961 classic text Death and Life of Great America Cities (published in German in 1963). Andreas Feldtkeller, who served as chief planner of Tübingen's new development areas recently reflected on Jacobs' influence, 
commenting that:

Very soon after my studies in architecture in the 1950s in Stuttgart and Berlin, the trend I noticed in planning [was] to neglect or entirely disregard important structural features of the city, which affect people's daily lives. My attitude was reflected in two books, both of which were published in 1963. Jane Jacobs' 'Death and Life of Great American Cities' [German translation] and Ludwig Hilberseimers' 'Entfaltung einer Planungsidee' ['Development of a Planning Idea'] which together presented a discussion typical of the time, of the balancing act between the conventional compact city and the more loosely structured planning approach.

Feldtkeller, 2012: 11-12

Feldtkeller identified in Jacobs' work a prescient framework for sustainable city planning, based on the following four essential ingredients for 'exuberant diversity' (1990: 150-151):

1. A district and constituent parts must serve more than one primary function;

2. Most blocks must be short and with frequent corners;

3. A mix of building ages that will provide some cheaper rents;

4. There must be a sufficiently dense concentration of people;

Of these four factors, Jacobs regarded the mix of primary functions - the integration of workplaces in a predominantly residential district as essential for creating a 'time-balance' of activity from workers during the weekdays and residents to sustain local businesses and the secondary diversity of retail, noting that:

In city districts that are predominantly or heavily residential, the more complexity and variety of primary uses that can be cultivated the better... the chief chessman that is needed in these districts is work.

(ibid: 174)

These principles, and notably the foundational concept of mixed primary functions, have been most distinctly applied in Tübingen's newly completed areas of the city's southern fringe or Südstadt urban extension. The leap from downtown New York to provincial Germany may appear both formidable and ironic - in view of the title of Jacobs' work, yet the principles set out are foundational for the operation of the short distances concept. This research seeks to determine the extent to which commuter travel has been affected by their application within a new urban extension to a small German city.

\section{The city of short distances model}


Tübingen is often eclipsed by Freiburg as a case study example of short distance planning (Hamiduddin, 2015a; Buehler and Pucher, 2011), where this guiding planning concept has been applied in the two well known new urban quarters of Vauban and Rieselfeld. In these quarters a combination of land use planning and urban structure have attempted to reduce travel need through the integration of community facilities, employment and retail. The latter forms a particularly distinctive element of short distance planning across Freiburg, where an 800sqm upper limit on retail store footprint, and an outright ban on out-of-town retail stores (with exemptions for those selling 'bulky goods' such as furniture or home improvement materials) sought to reduce travel distances by decentralising and distributing retail stores into each neighbourhood (Buehler and Pucher, 2011). This pattern of dispersion to reduce travel distance has potentially important social as well as environmental implications, in terms of equality of access and opportunity to facilities and amenities, by reducing the need for costly travel - particularly by automobile (Hamiduddin, 2015b).

In Tübingen, short distance planning formed a central theme for the Südstadt scheme. In the 1993 masterplan Andreas Feldtkeller declared that this 'mixed-use urban area with high density is also to be a "city of short distances' (City of Tübingen, 1993). In this particular scheme the term 'mixed use' means the concentration of employment generating land uses with residential development, with focal points created on the two former military areas of Loretto and the Französich Viertel (French Quarter). The 1993 Südstadt masterplan established an overall target for the creation of a 1:1 ratio of new jobs created per new homes constructed, with this 1:1 ratio applied specifically at Loretto and a more modest 0.4 target applied at the more suburban French Quarter site. These objectives were ambitious given that Freiburg achieved more modest ratios of 0.25 and 0.27 at Vauban and Rieselfeld. (Hamiduddin, 2015a). Feldtkeller's vision was to create a diversity of small-scale employment, ranging from pre-industrial style artisan workshops, postindustrial service sector practices, and small-scale manufacturing units. The key to achieving this was a planning ordinance requiring all residential buildings to include non-residential uses in the ground floor units adjacent to streets and public spaces. Several of these manufacturing operations are located within the lower floors of residential buildings, a most symbolic reversal of zonal planning that modern clean and quiet production methods were able to permit. 


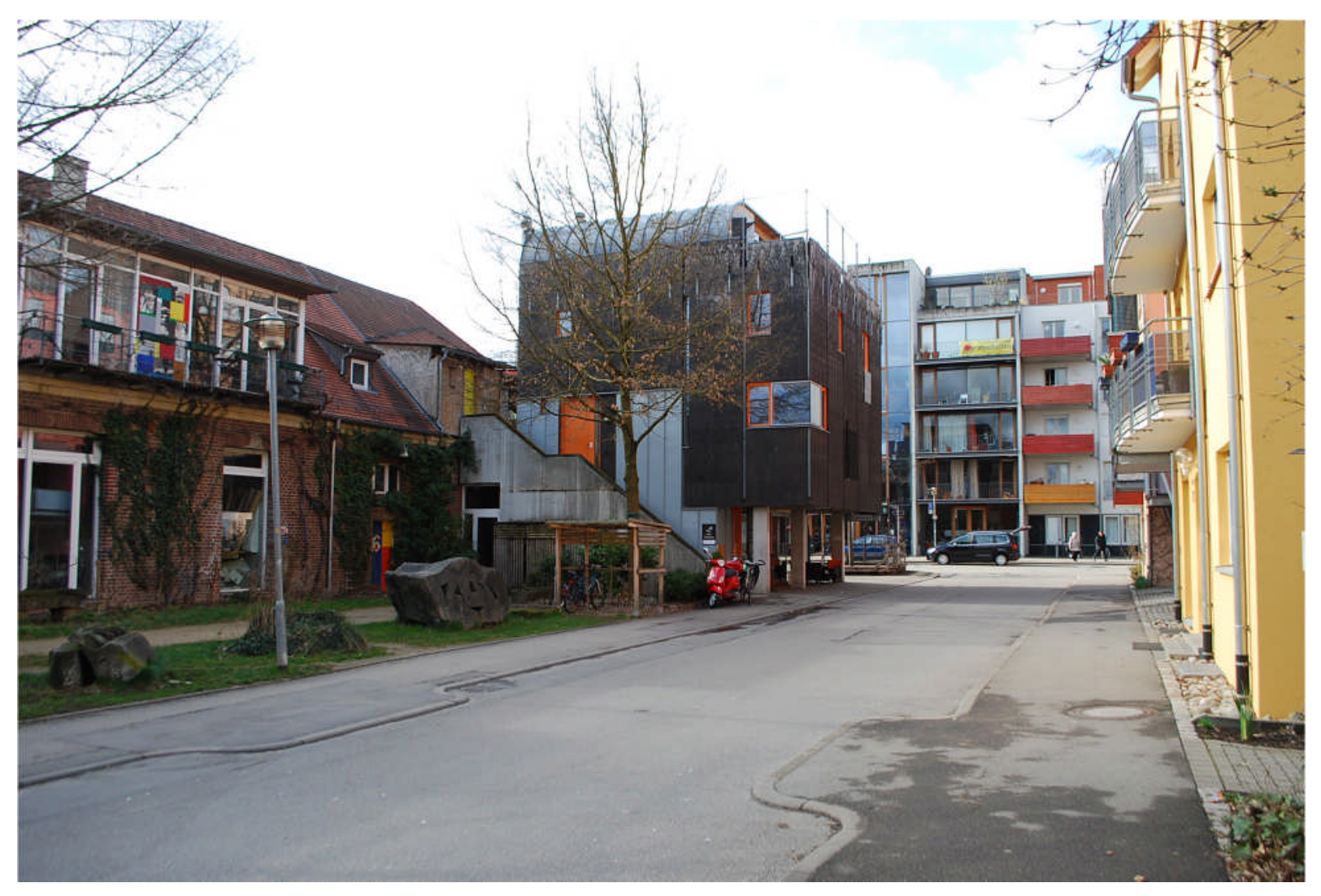

Fig.1 The integration of mixed uses and building ages in the French Quarter.

Though distinctive in its attempt to incubate a strong local economy through production, Tübingen's Südstadt was one of several schemes established across Germany and Switzerland in the early-to-mid 1990s to attempt to create employment focussed mixed-use development on urban brownfield land (Feldtkeller, 2001). Other examples included Berlin's Viktoria Quartier, Zürich West and Essen's Weststadt. In Tübingen, the aspiration was to create an authentic new 'piece of the city' (Feldtkeller, 2015:16) that would integrate and function as an integral part of a wider urban system, based on the medieval urban core. This broad ambition was to be operationalized through five key structuring elements set out in the masterplan (Betz, 2011; City of Tübingen, 2012a), and it is notable how the following principles appear to correlate with Jacobs' four essential ingredients:

1. Block style urban structure

2. Integration of small scale mixed-uses

3. High density and integration of old buildings into the development

4. Attractive public space and car-reduced traffic concept

5. Self-build method of residential development

Elements one and two recall the primary functions and short blocks that Jacobs identified as two key ingredients for urban vitality, while four prioritises social interaction within each neighbourhood, by 
achieving a secure environment through good natural surveillance and opportunities for casual social encounters. Element three responds to Jacobs' requirement for a range of building ages, to provide both diversity in tenures and affordability, and also - in the specific context of the Südstadt - to create a sense of place identity and historic continuity through an interesting mix of old and new architecture. The mode of building construction, as set out in the fifth element, is Tübingen's own unique ingredient regarded both as an integral 1 aspect of place-making and a means for housing affordability. Group self-build or Baugruppen have been encouraged as the prevalent means for new housing production in Loretto and the French Quarter, achieving a visual complexity through a mix of individual building styles and characteristics chosen by the occupants of each under a permissive design framework set out in the masterplan. The resulting structured informality in building style, coupled with the permeable pedestrianoriented layout of the scheme recalls Tübingen's historic altstadt.

The main task of this research has been to try to identify the main travel outcomes from the tight integration of land uses created, to address the key question: has the emphasis on mixing housing and employment in Loretto and the French Quarter created more sustainable commuting patterns, including a reduction in commuting distances and higher levels of walking and cycling? The research has not set out to perform a full dissection of the model to identify causality of travel outcomes in relation to particular variables, but to investigate the economic viability of the short distances model for employers, travel implications for employees and indications of other social effects associated with travel reduction. These concerns are reflected in the following three sub-questions that have assisted in operationalizing the main research question: (i) what are the key effects of the short distance planning model for employers?, (ii) to what extent do the commuting patterns of short distance model employees differ from control neighbourhoods?, and (iii) what are the key social effects of residential and employment co-location?

\section{Integration of primary uses: feasible and desirable?}

This section explores the feasibility and desirability of employee-employment proximity by land use integration in relation to three different groups. The first is the perspective of employing organisations and how the quest for co-location may have an intrinsic bearing on the viability of that organisation. The second is the external perspective of employees, customers, suppliers and visitors requiring access to an organisation from outside, while the third group are the employees themselves, and the wider social implications that distance reduction may bring to bear on this group. Two distinctive mechanisms may be identified for travel reduction among residents as a result of the mixing of primary land use functions. The first can be described as primary reduction in commuting travel as a direct consequence of the colocation of employee with workplace, while the other can be described as the secondary reduction that relates to the reduction in travel from home to retail stores, cafes, bars and other enterprises described by Jacobs as 'secondary diversity'. The latter stems from the mix of different primary functions in an area that creates customer footfall at different times, such that it permits vibrant secondary diversity to be sustained with the effect that residents who work well away from their home can experienced reduced travel in other areas of life, although this effect may be subdued by trip-chains or activities added to a work commute (dropping children at school en route to work for example) or activities undertaken near their workplace (shopping or seeing friends at lunchtime for example). 


\section{Employing organisations}

In relation to the three different theoretical perspectives outlined above, the first group to consider are the employing organisations whose long-term economic health and sustainability are essential drivers of locational decision-making. It is not immediately clear which type of businesses and organisations would be most suited to fine grain mixed-use planning and how the tight integration within a largely residential setting could affect long-term needs including evolution and physical expansion. Offices and factories are cited by Jacobs as primary uses that are suitable for mixing with residential development, maintaining high levels of 1 continuous activity rather than 'dormitories' devoid of life during the working day. Jacobs illustrates her argument with reference to smaller scale workplaces that can fit comfortably within the neighbourhood setting, amidst dwellings and other uses, and without unduly disrupting the permeability of local urban structure. This is a co-location model that creates a 'time spread' of users that support secondary diversity and, in sum, creates a self-reinforcing activity 'hive'. Jacobs described these areas as 'incubators' of activity (1990:165), where success often breeds further success (1990:167). Start-ups and small enterprises are signifiers of incubation and dynamism. Yet there remain questions firstly over whether these start-ups and smaller organisations have the necessary physical space to up-scale within the neighbourhood setting, or whether they can access the necessary workforce skills to expand within the available labour pool.

Physical setting and access to workforce skills are key factors that affect business location across different sectors. Heavy industry and manufacturing, traditionally focus on economic climate, productivity, transportation, land availability and development costs (Hekman, 1982), while the high tech and knowledge-based sectors tend to prioritise the availability of skilled personnel, the ambiance and lifestyle of an area, and the personal preferences of the owner (Galbraith, 1985). Although a diverse range of employment is available within the Loretto and French Quarters areas, small organisations and businesses are particularly well represented. These organisations tend to emphasise employee flexibility and 'softer' factors including lifestyle and job satisfaction alongside financial factors including growth (Walker and Brown, 2004). Childcare and family arrangements can also be an important motivation for small business owners. As Walker and Brown (2004:587) note:

Often, being able to structure their working arrangements in order to free up time was an important feature of being the owner of a [small] business. This allowed them to do personal activities such as mind their young child so their partner could continue their career or go for a long lunch, without having to explain their actions to anyone. These aspects of flexibility are generally not available in large organisations.

In relation to the workplace itself, Jacobs regarded a mix of different building ages as being vital for creating affordable premises for start-ups and smaller businesses in cheaper older buildings whose capital costs no longer needed to be covered, while established or larger enterprises could benefit from a more tailored, 
modern workplace environment. The Loretto and French Quarter areas both include a mix of old workshop buildings and new-build mixed-use buildings, providing a spectrum of workplace accommodation that conform both to the spirit and letter of Jacobs' logic, albeit primarily as a means to contribute to place identity. Although the quieter and low polluting nature of smaller craft and manufacturing production processes now make many compatible neighbours to residential dwellings, some are not and many require access by goods vehicles that can be potentially problematic and undesirable in the residential environment. There may also be long-term issues over the potential for an organisation to grow within a particular locality. It is a quite usual for an organisation to a strategic relocation to expand or develop, but in this case a dilemma could be reached between in situ stagnation or losing the benefits associated with co-location.

\section{Inward Access}

The second aspect concerns wider geographical access of a locality for employees, customers and visitors, and also for the inward and outward movement of materials and goods, given the broad aim of compact city planning to minimise automobile movements. There is particular scope for tension between the needs of local residents and employing organisations if there are significant levels of inward commuting by car. In any case, achieving a balance between residents and employment is unlikely to be achievable, and particularly for households with multiple incomes or parity between wage earners, particularly in more skilled professions.

It would therefore be quite usual for employees to be drawn from a wider catchment or travel to work (TTW) area whose daily commute requirements may feasibly be met by public transport in large urban areas. In the case of a small city set in a largely rural region in the case of Tübingen, the private car may provide the only practical commuting option from the outlying TTW, and with it the potential for generating considerable levels of external traffic into a neighbourhood setting. Without careful consideration, physical measures introduced to mitigate the objective dangers and disruption from traffic will alter the characteristics of a place, particularly by turning streets away from social spaces and into areas designed to optimise the throughput of traffic. For productive industries, the movement of freight vehicles to deliver materials and collect finished goods superimposes additional challenges that now seem to have been oddly overlooked by Jacobs in her examination of employment primary uses and traffic.

In reality however, a number of design measures have sought to avoid or mitigate the potential conflict between incoming road traffic and local residents at the French Quarter. Car parking has been strategically placed around the perimeter of site, with most convenient access by way of boundary roads around the western and southern edge of the site (Fig.2) to minimise traffic within the inner core, where car parking is largely limited to expensive, on- street visitor parking bays. The small industrial units within the site are most easily accessed via the same boundary roads, to prevent the blight caused by heavy goods vehicles.

\section{Fig.2 French Quarter site layout}




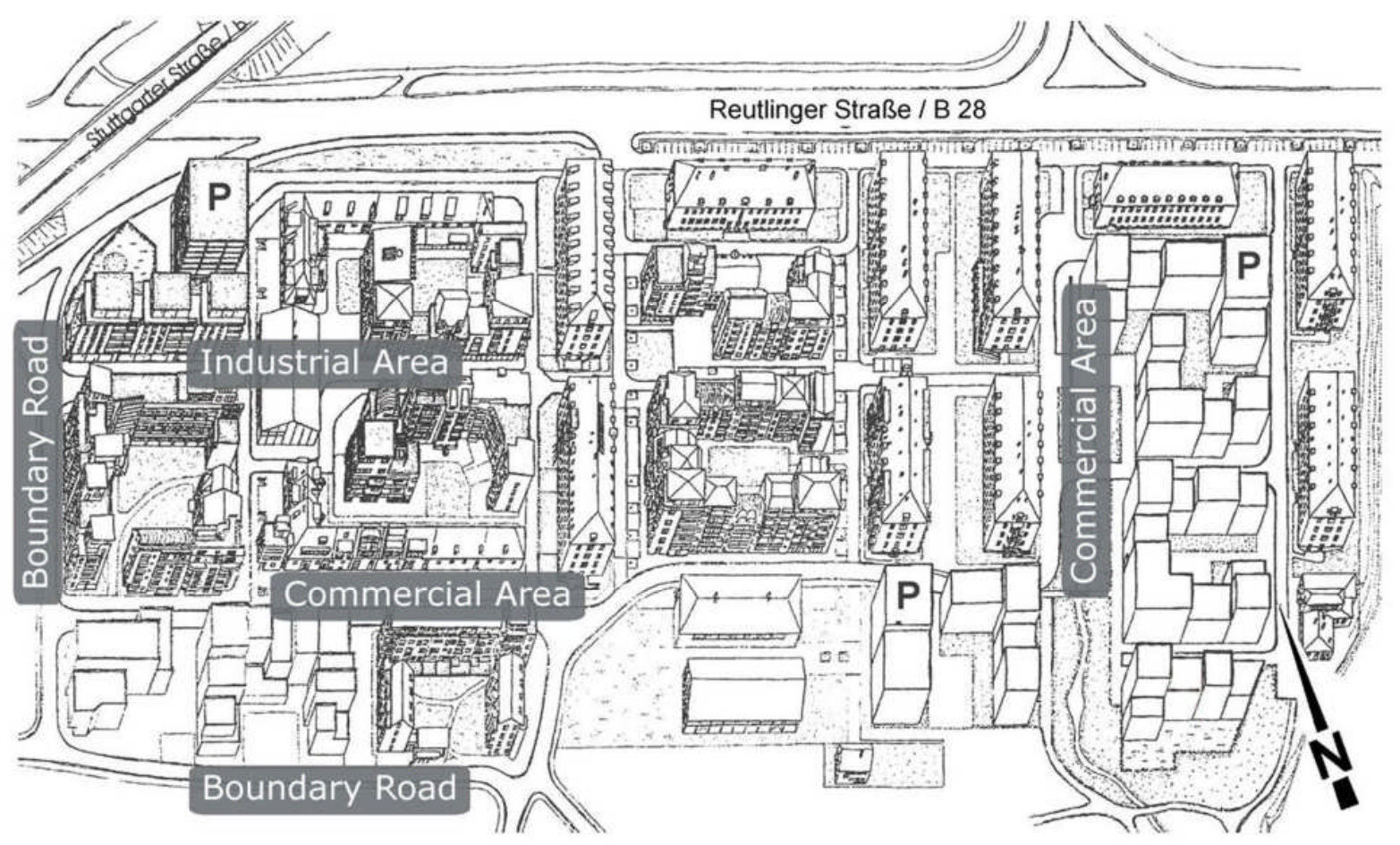

Fig.2 French Quarter site layout

\section{Employees}

A third and final area of uncertainty concerns the desirability for employees of living close to the workplace. In terms of workplace access, co-location may be particularly helpful for parents balancing work with childcare responsibilities because childcare and education facilities tend to be located close to large residential developments. Moreover, the combination of close spatial proximity between home, workplace and childcare / education facilities, plus the potential for greater flexibility in working arrangements that smaller employers tend to permit could combine powerfully to reduce the barrier that childcare can present as a barrier to employment (Chevalier \& Vitanen, 2002). The literature suggests a strong likelihood of demographic skewing through residential self-selection (Cao et al, 2009; Bohte et al, 2010, Hamiduddin, 2015a) because families (particularly those with younger children) are drawn to neighbourhoods that offer spatial proximity between home, workplace and community facilities, and an objectively safer low car neighbourhood environment.

It is also possible that constrained lifestyle geography may also create a sense of claustrophobia or an unmet travel need that may manifest itself through the displacement of work to leisure travel. The latter effect may be linked to fixed travel time budget theories in which it is proposed that travel 'saved' in one realm of life may be 'spent' in another as Holden and Linnerud (2011) depict in their 'troublesome leisure travel' thesis. Using travel data from Oslo, the authors indicating an inverse correlation between residents dwelling in compact inner city districts with short day-to-day commuting distances and compact lifestyle geographies and long-distance leisure travel. The authors suggest Travel Time Budget theory (Mokhtarian and Chen, 
2004) as an explanation for this pattern and leisure travel as a 'coping mechanism' for compact urban living - in effect a 'release valve' to the cumulative claustrophobia of dense urban living. To date, evidence of fixed travel time expenditure has been identified only at the higher order aggregation of national travel data (Metz, 2008), while disaggregation of available data shows significant variances of travel, perhaps 1 indicating that travel time tolerances and preferences differ between individuals or groups.

\section{The Empirical Research}

Two batches of primary qualitative and quantitative data were collected to address each of the three research sub-questions, investigating in turn the viability and effects of short distance planning for employers, the effects on employee travel, and the wider social effects of co-location. The first batch of data consisted of qualitative material obtained from five semi-structured interviews that sought to cover the multiple perspectives including intended outcomes of the short distances model from a local planning perspective, outcomes an employer point of view, and employee insights to supplement a batch of questionnaire survey data. The interviewees consisted of: (i) a male retired planner responsible for the original Südstadt plan, (ii) a male planner now responsible for Südstadt development, (iii) a male owner of a medium-sized manufacturing company located in the French Quarter, (iv) a female office manager for a large German NGO, and (v) a female self-employed media agent. All interviewees were comfortable to conduct the interviews in English, although translation assistance available for interviews iii to v.

The second batch of material consisted of questionnaire survey data which compared samples of employees from the Loretto and French Quarter neighbourhoods of the Südstadt district - together described as the 'short distance cluster' against a control sample of employees located in the Lustnau and Derendingen districts of outer Tübingen (Fig.3) - the 'control cluster'. By including two neighbourhoods within each of the two data batches allowed a larger data sample to be collected and a more representative cross section of urban layout, housing types and tenures, and spatial proximity to non-residential uses to be included within each of the two clusters. Potentially sensitive personal information including income and age were not included on the questionnaire survey as they were not deemed to be necessary and may have prejudiced the overall response rate. 


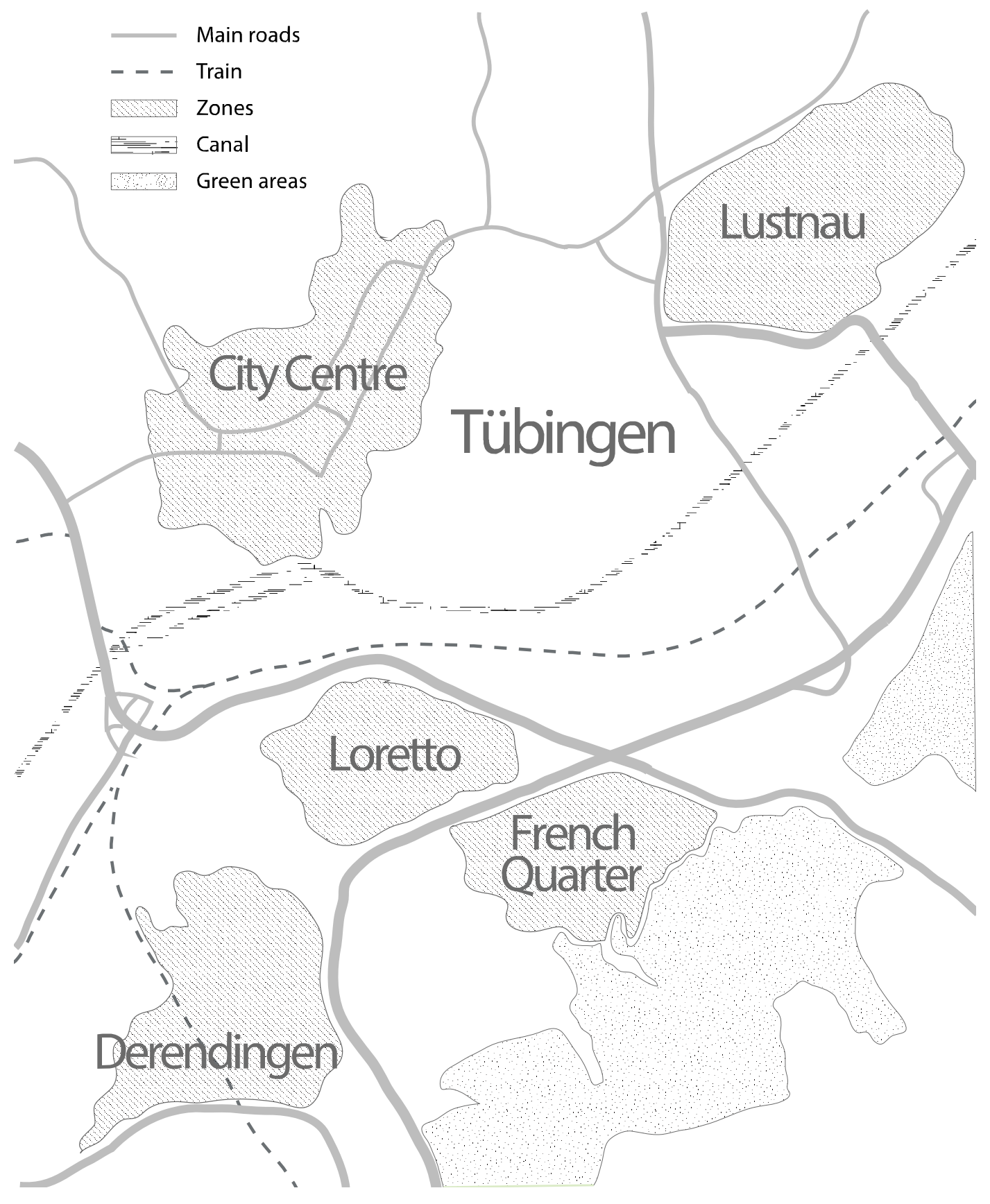

Fig.3 Map showing research localities

Case Study Sites

The Loretto and the French Quarter areas form keystone schemes of the Südstadt southern fringe development, a 65 hectare urban extension begun in the late 1990s that is now home to over 6000 residents. 
Loretto is the smaller and more urban of the two schemes - with 900 residents and an estimated 500 employees (City of Tübingen, 2013) - formed around the Loretto Platz (the parade square of the former military barracks) approximately $1.5 \mathrm{~km}$ from the city centre (Fig.1). The larger French Quarter scheme is located on the southeasterly fringe of the city approximately $3 \mathrm{~km}$ from the city centre with 2350 residents and approximately 700 jobs (City of Tübingen, 2013) - up from the original target of 500 jobs due to the recent expansion of several employing organisations. Both schemes have district level retail and services on offer, including a secondary school at Loretto, together with small-scale offices, studios and manufacturing units. The two schemes jointly have approximately 3250 residents in 1400 homes, and provide 1200 jobs, representing 4\% of Tübingen's population and 3\% of all jobs, with an overall homesjobs ratio of almost 0.9 .

The two control neighbourhoods of Lustnau and Derendingen are long-established districts of the city that developed as entirely separate settlements until incorporation into the city in 1934. Derendingen which is located close to Loretto approximately $2 \mathrm{~km}$ from the city centre has an overall population of nearly 7000 inhabitants but 1800 residents live within the central part of the district (City of Tübingen, 2015) adjacent to the civic centre. Employing organisations include the typical range of district-level retail and services. Lustnau, which is located $3 \mathrm{~km}$ east of the city centre is similar in character to Derendingen although outlying neighbourhoods give this municipality a larger overall population of just over 10000 inhabitants, of which 3000 live within the central area. Derendingen and Lustnau are both characterised by suburban style family housing, small retailers in and around each civic centre and a handful of larger employers such as small manufacturers, schools and care homes. Detailed employment data is not available for these districts. 


\begin{tabular}{|l|l|l|}
\hline & $\begin{array}{l}\text { Short Distance Cluster } \\
\text { Loretto + French Quarters }\end{array}$ & $\begin{array}{l}\text { Control Cluster } \\
\text { Lustnau + Derendingen }\end{array}$ \\
\hline Scale & $\begin{array}{l}1400 \text { homes (400 Lor / 1000 Fr } \\
\text { Qr) }\end{array}$ & $\begin{array}{l}\text { 5000 homes (1600 Lustnau / 3400 } \\
\text { Derendingen) }\end{array}$ \\
\hline Population & $3500(1000 / 2500)^{1}$ & $10000(3200 / 6800)$ \\
\hline $\begin{array}{l}\text { Employment } \\
\text { Opportunities }\end{array}$ & $1200(500 / 700)^{1}$ & No data \\
\hline Description & $\begin{array}{l}\text { New sustainable living quarters, } \\
\text { part of the Südstadt urban } \\
\text { extension. Particular emphasis } \\
\text { on mixed land uses. Main } \\
\text { construction phase ended in } \\
\text { 2007. }\end{array}$ & $\begin{array}{l}\text { Historic outlying settlements that } \\
\text { became incorporated into the city } \\
\text { in 1934. Both retain strong } \\
\text { andendent identities } \\
\text { facilities. }\end{array}$ \\
\hline
\end{tabular}

Table 1: Survey site characteristics

\section{Employee Questionnaire Survey}

Approximately three quarters of respondents completed the questionnaire by drop-off and collection at a later time, while the remaining quarter completed it through structured interviews with the surveyors, who were native German speakers. The composition of survey respondents is given later in table 4 . The sample size differences between Loretto / French Quarter $(n=154)$ and Control cluster $(n=93)$ reflects the number of employing organisations located in each district.

In order to investigate the effects of short distance planning on employee travel and social habits, the questionnaire asked employees about their work travel patterns and leisure time activities and social relations within their neighbourhood, as well as a typical set of background factors to compare the profile of respondents, which are shown below in table 2. The control sample indicates pronounced gender influences in employment structure, whereby a greater proportion of part-time employment and a lower proportion of employees deemed to be the primary earner the household appear to be linked to a greater proportion of female employees - a pattern substantiated in further analysis of the data. It might be assumed that this pattern would be influenced by traditional gendered roles in relation to childcare and the family, even though the proportion of under 18 year olds is appreciably lower in the Control Cluster (15.6\%) than

\footnotetext{
${ }^{1}$ http://www.tuebingen.de/loretto\#1608 (accessed 08 Oct 13)
} 
in the Short Distance Cluster (19.7\%), and similar to the average for the city (14.6\%) (City of Tübingen, 2012b). One potential effect of short distances planning, in which work, home and childcare facilities are located in close proximity, may be greater gender equality in terms of higher levels of full time work and primary earning among women with childcare responsibilities. Certainly, the data indicates that this might be the case although it cannot be conclusively proven from this limited data set. Table 1 also shows that the Short Distance Cluster is characterised by a greater proportion of small organisations, employing under 50 members of staff, and also a greater proportion of public or non-profit sector organisations that constitute approximately a quarter of all organisations there.

\begin{tabular}{|l|l|l|}
\hline Employee Characteristic & $\begin{array}{l}\text { Control Cluster } \\
(\mathrm{n}=92)\end{array}$ & $\begin{array}{l}\text { Short Distance Cluster } \\
(\mathrm{n}=154)\end{array}$ \\
\hline Male / Female & $35 / 65 \%$ & $51 / 49 \%$ \\
\hline Household primary earner & $45 \%$ & $61 \%$ \\
\hline Full time / part time / flexible & $58 / 39 / 3 \%$ & $64 / 26 / 10 \%$ \\
\hline Private / public sector & $84 / 16 \%$ & $76 / 24 \%$ \\
\hline Organisation employees $<50 / 50-200 />200$ & $73 / 13 / 14 \%$ & $87 / 6 / 7 \%$ \\
\hline
\end{tabular}

\section{Table 2: Key characteristics of employees surveyed in the two clusters}

\section{Findings}

This section addresses each of the three research concerns and attendant sub-questions in turn. Employee surveys across the two survey clusters provide headline data in relation to co- location and commuting patterns. At the Südstadt, $37 \%$ of survey respondents lived locally within the district - compared to $23 \%$ in the control cluster (Table 3). As the survey was conducted among employees rather than households, it should not automatically be concluded that these patterns would necessarily be consistent across the resident populations of each neighbourhood. It is also not clear whether the greater level of work-housing co-location among short distance cluster employees reflects the greater significance of this factor in overall lifestyle choice. However, the greater proportion of co-location among short distance cluster employees also helps to explain the slightly shorter overall average commuting time of 19.3 minutes, compared to 21.1 in the control cluster sample. 


\begin{tabular}{|l|l|l|l|}
\hline Category & Variable & $\begin{array}{l}\text { Control } \\
\text { Cluster }\end{array}$ & $\begin{array}{l}\text { Short } \\
\text { Distance } \\
\text { Cluster }\end{array}$ \\
\hline Co-location & Neighbourhood resident & $23 \%$ & $37 \%$ \\
\hline \multirow{3}{*}{ Work travel } & Permanent car access & $75 \%$ & $72 \%$ \\
\cline { 2 - 4 } & Car commute & $58 \%$ & $37 \%$ \\
\cline { 2 - 4 } & Commute average duration & $21.1 \mathrm{~min}$ & $19.3 \mathrm{~min}$ \\
\cline { 2 - 4 } & Satisfaction with commute & $80 \%$ & $68 \%$ \\
\hline
\end{tabular}

Table 3: Co-location and work travel patterns among employees surveyed

\section{Effects of short-distance planning for employers}

In general terms, the experience of locating a business or organisation within a largely residential locality was found to have been a broadly positive one, the necessary conditions of appropriate workforce, supporting activities and appropriate premises broadly having been met. The critical issue of jobs-skills balance seems to have been negated by an employment structure in which workforce skill is inversely related to the size of organisation. Specialist organisations such as knowledge-based consultancies, agencies or medical practices tend to be very small - often a proprietor operating alone or with one or two employees. Larger organisations in the short distance cluster tended to have a less skilled workforce. Interviews conducted with two employers based in the Südstadt [male company owner and female head of bureau] suggested that co-location here works only with very small businesses - typically start-ups and the selfemployed attracted to the relatively small work premises at the ground floor of each residential building, and those requiring only the small number of specialist staff who are likely to be found within a relatively limited local catchment. The survey data also indicated that the greater majority of respondents were from small organisations with fewer than five employees. The short distance cluster's high level of co-location, mix of primary business and organisational employment, and rich secondary diversity of retail and services indicates strong mutual support provided through time balance of footfall in the district.

The allocation of suitable employment and commercial space has been slightly problematic in Loretto and the French Quarter. Three interviewees [male company owner, male current planner, female head of bureau] thought that the utilisation of non-residential ground floor space required by the original planning ordinances had reached its peak level in the Südstadt a few years previously. The initial over-supply of nonresidential space has led to long-term vacancies and some ground floor units have never been occupied. The protective ordinances have therefore been rescinded in some buildings to allow the conversion of these premisesinto residential quarters. Such relaxations have been building specific and have had not amounted to a policy change that has had wider land use impacts. Further issues of workspace adaptability and the ability to meet the needs of business growth were identified in the case of a medium sized manufacturing 
company located centrally within the French Quarter. This particular company was able to expand its operations by acquiring a second workshop premises across the street from the original site - a compromise made practical because of the close proximity of the two sites, but potentially a more expensive choice in the long term, compared to relocating to a single site. In this particular case the company owner is a strong supporter of the city of short distances concept, having located his business from a village to the French Quarter to enable him and the majority of his workforce to live close to their workplace. The company is effectively locked-in to its locality in a manner reminiscent of an earlier company town or village. Relocation of any distance out of the quarter would cause significant disruption for a workforce assembled largely on the principle of proximity, on the other hand, remaining in-situ brings its own risks, including potential stagnation or higher overheads from sub-optimal workspace.

The spatial and temporal overlapping and overlaying of employment, domestic and social spheres that colocation entails is scarcely a new phenomenon, but it does present a departure away from the trend of greater lifestyle dispersion that transportation has facilitated since the Industrial Revolution. Spatial integration requires social re-integration and the compaction of relationships that can be viewed as both an enriching and claustrophobic experience - offering comfort but also fewer options to escape awkwardness. Uncomfortable situations can arise if relations between employer and employee become strained or the duty felt by an employer to provide work if approached by a neighbour, for example, or, conversely, if there are pressing domestic issues. However, these potentially negative concerns should not be overstated. In smaller organisations, employee and employer will often quickly recognise if their relationship is not working. This is largely because workforce relations in small businesses tend to be more personal and open:

It is normally a mutual feeling [...] normally we don't have this problem, but for other employers I can imagine that it is better to have employees that come from far out - it is easier. But normally for small companies often your colleagues are your friends and you are used to having this problem.

\section{[male company owner]}

Although the application of short distance planning can create a compaction of life geography and social relations, greater propinquity - the shared occupation of time and space by several individuals - can counteract time-savings in travel. In fact, the density of social interactions can make for a very slow journey around the neighbourhood, or - in the case of one interviewee [male company owner] - even across the street from home to workshop:

When your distances are short, there are probabilities that you will meet your neighbours [...] the ways are short - in kilometres - but not in time!

\section{[male company owner]}

The integration of employment space in a largely residential setting can provide the necessary level of daytime economic activity that can directly sustain a diversity of retail outlets, cafés and other commercial spaces. These can in turn provide opportunities for neighbourhood social life and reduced distances between 
residents and retail. By contrast, it can be difficult to sustain a diverse local economy through evening and weekend economic activity alone. Both sets of employee data illustrate the potential contribution of employees to a local economy. In both cases, table 4 shows that two thirds of employees reported using local retail outlets occasionally or frequently, and an even greater proportion used cafés or restaurants close to the workplace, although the markedly lower (yet still high) proportion of frequent café and restaurant users within the short distance sample may be due to the greater level of co-location there, and the higher proportion of employees dining at home - at lunchtime, for example.

\begin{tabular}{|l|l|l|l|}
\hline Category & Variable & Control Cluster & $\begin{array}{l}\text { Short distance } \\
\text { cluster }\end{array}$ \\
\hline $\begin{array}{l}\text { Frequent use of } \\
\text { facilities }\end{array}$ & Retail & $64 \%$ & $68 \%$ \\
\cline { 2 - 4 } & Cafes \& restaurants & $89 \%$ & $72 \%$ \\
\hline
\end{tabular}

Table 4: Use of neighbourhood facilities by employees

\section{Access for incomers}

Although the proportion of employees living in close proximity to the workplace is significantly higher in the short distance cluster than in the control cluster, the importance of the workplace in residential location was consistent for both sets of employees at approximately $70 \%$ (Fig. 4), but was less important to a greater proportion of short distance cluster employees (18\%) compared to those of the control cluster (12\%). Caution must be exercised in drawing firm conclusions from a limited data sample. A straightforward explanation for this finding is that workplace location is simply a lesser priority than others (for example, education and childcare facilities or housing affordability) in residential decision-making, however there was no clear pattern to suggest that co-location was a more important factor to those living within the short distance neighbourhoods, compared to those living outside. 


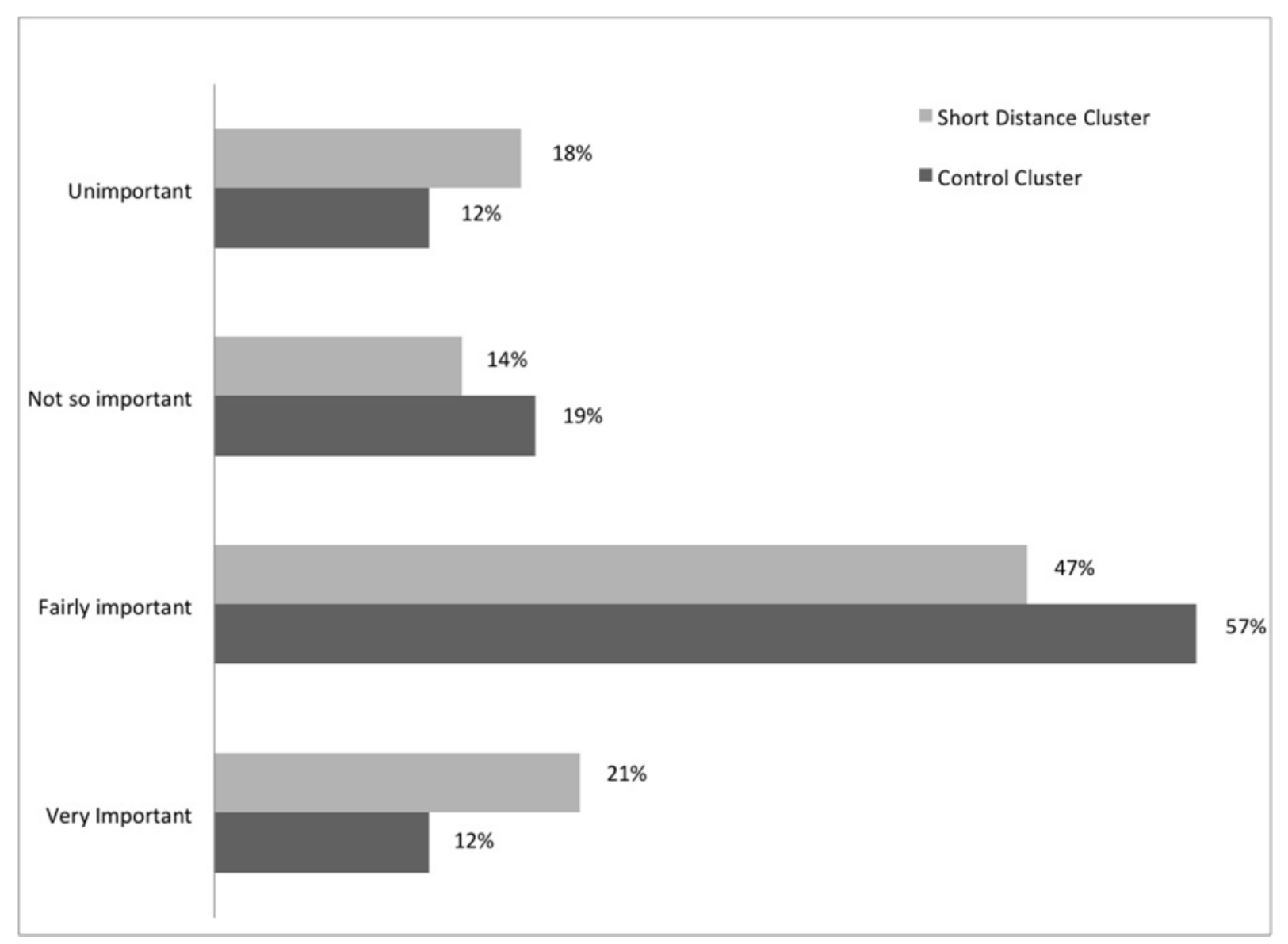

\section{Fig.4 Importance of workplace location in residential decision-making}

A higher level of housing-work co-location among short distance cluster employees does reflect quite strongly in the modal share of commuter travel both in aggregate and when the data is disaggregated geographically. In aggregate, the car was the major mode of transport for 37\% of short distance cluster employees, compared to 58\% in the control cluster (Fig.5). Similarly, aggregate levels of cycling and walking among Short distance cluster employees (49\%) are double the level found within the control cluster sample (25\%). 


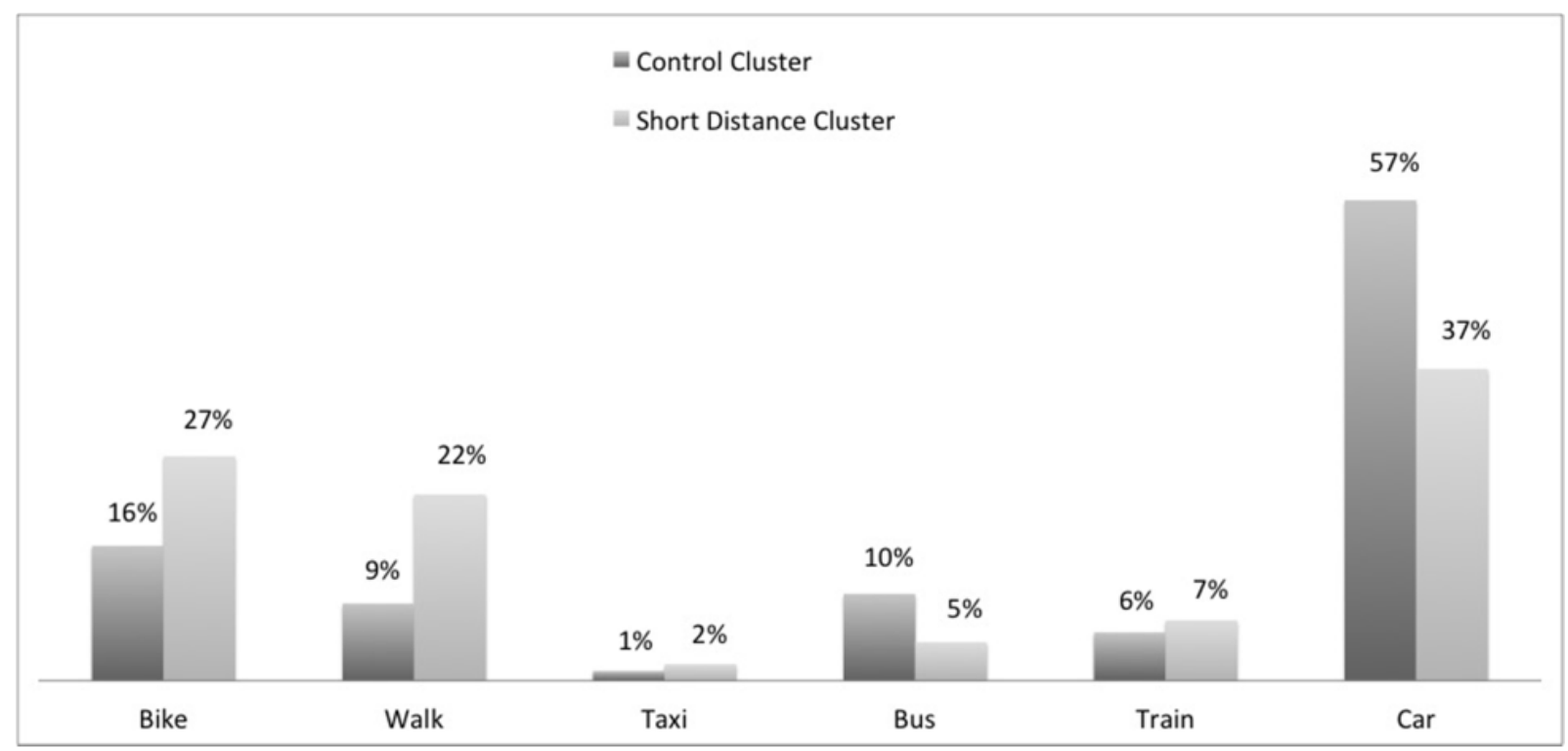

\section{Fig.5 Commuter modal share patterns}

These headline travel patterns are supported by the disaggregation of the travel data into three commuter categories: (i) those from outside of the neighbourhood but within Tübingen city, (ii) those from elsewhere in the region, and (iii) those from within the neighbourhood. Significant contrasts are revealed in patterns of car use. Given that public transport access was similar across both of the clusters, this seems to reflect the different provision for the private car in each neighbourhood. The relatively small survey sample of employees that constitute each class of commuters means that the disaggregated data needs to be treated with some caution. Nevertheless, table 5 indicates a number of striking patterns - notably the substantially lower proportion of employees commuting by car from regional town and villages to the Südstadt (65\%) compared with the control cluster $(81 \%)$ and the very small number of employees commuting locally by car within the Südstadt district (7\%) compared to approximately one third in the control cluster. Across each of the survey localities, car commuting from other districts within Tübingen city represented approximately one third of modal share. Once again, a likely explanation is the limited availability of relatively expensive non-resident car parking in the Südstadt.

\begin{tabular}{|l|l|l|}
\hline Origin of Commuters & $\begin{array}{l}\text { Control } \\
\text { Cluster }\end{array}$ & $\begin{array}{l}\text { Short distance } \\
\text { cluster }\end{array}$ \\
\hline Tübingen City & $33 \%$ & $39 \%$ \\
\cline { 2 - 3 } The Region & $81 \%$ & $65 \%$ \\
\cline { 2 - 3 } Local Neighbourhood & $35 \%$ & $7 \%$ \\
\hline
\end{tabular}

Table 5: Car-based work travel by employee origin 


\section{Social implications and neighbourhood life}

The research considered the wider social effects of living and working within the neighbourhood by asking residents how frequently they typically socialised with their neighbours and how many evenings they spent outside of their neighbourhood in a typical week. The data analysis compared in aggregate all employees who lived and worked in the neighbourhood and all those that were not co-located, and the data was similarly divided for each neighbourhood (table 6). Although sample size varied considerably across the different data sets, consistent patterns are evident across the data. These are evident across the background factors in relation to travel. Access to a private car was found to be virtually uniform across co-located and non-co-located employees, while amounts of time working at home (days per week) were also found to be consistently low between the data sets. The duration of time spent commuting varied in a manner consistent with proximity between home and workplace with a five-fold variation in commuting times between those who were co-located and those who were not.

\begin{tabular}{|c|c|c|c|c|c|c|}
\hline & \multirow{2}{*}{$\begin{array}{l}\text { All } \\
(\mathbf{n}=\mathbf{7 1}) \\
\text { Co-located } \\
\text { employees }\end{array}$} & \multirow{2}{*}{$\begin{array}{l}\text { All } \\
(\mathbf{n}=\mathbf{1 7 5}) \\
\begin{array}{l}\text { Employees not } \\
\text { colocated }\end{array}\end{array}$} & \multicolumn{2}{|c|}{ Control Cluster } & \multicolumn{2}{|c|}{ Short Distance Cluster } \\
\hline & & & $\begin{array}{l}\text { Co-located } \\
\text { employees } \\
(n=21)\end{array}$ & $\begin{array}{l}\text { Employees } \\
\text { not } \\
\text { collocated } \\
(\mathrm{n}=71)\end{array}$ & $\begin{array}{l}\text { Co-located } \\
\text { employees (n } \\
=50)\end{array}$ & $\begin{array}{l}\text { Employees } \\
\text { not } \\
\text { collocated (n } \\
=104)\end{array}$ \\
\hline $\begin{array}{l}\text { Home working (ave 1-5 } \\
\text { days per week) }\end{array}$ & 0.7 & 0.6 & 0.8 & 0.5 & 0.7 & 0.7 \\
\hline Commute dur (minutes) & 5.1 & 25.9 & 6.4 & 25.3 & 4.6 & 26.3 \\
\hline Socialise freq (ave, 1-5d) & 2.4 & 2.7 & 2.5 & 2.6 & 2.4 & 2.7 \\
\hline Evening out (ave, 1-5d) & 1.6 & 2 & 1.6 & 2.2 & 1.6 & 1.9 \\
\hline Years resident in home & 12.8 & 12.5 & 17.6 & 12.9 & 10.8 & 12.2 \\
\hline
\end{tabular}

Table 6 Work and social travel patterns

In relation to travel time budget theory, the data did not indicate any displacement of travel - such as through increases in leisure time spent outside of the neighbourhood that may have been anticipated. In fact, the data suggested a slight yet consistent pattern of stronger social relations within the neighbourhood among the short distances sample and, in turn, a significantly greater amount of leisure time spent by these residents within their neighbourhood. Although these findings are indicative rather than conclusive, being based on narrow indicators rather than comprehensive audits of individual travel and activities, they do suggest that propinquity may have played a role in enhancing social relations - and with it, an attendant reduction in leisure travel. Less clear is the foundational role of residential self-selection in creating a neighbourhood community conducive to strong social relations, or in matching residents to a physical setting that suits their leisure time preferences. 


\section{Concluding Discussion}

To explore the overall effects of short distances planning on work travel patterns, this exploratory research investigated the viability of the model for employing organisations, the effects on travel for incoming employees and visitors, and, finally, the work travel and social implications for employees resident close to their workplace.

Regarding the viability of the model for employees, the $37 \%$ of employees co-located close to their workplace in the Loretto and French quarters represents a considerable achievement and, in all likelihood, the upper boundary of practicability for a new edge-of-city development when the constraining effects of work-skills balance and residential location decision-making for multi-income households are considered. Indeed, under the ordinary circumstances of de- coupled housing and employment markets, policies to encourage co-location would best suit smaller and lower skill industries or where the workforce requirements can easily be met within a local area. However, the self-build model of residential development that formed one of the key planning features of Loretto and the French Quarter may make the stability of employment structure difficult to maintain over the long term. This is because the original residents benefited from the substantial cost saving equivalent to the profit margin of a commercial developer (Hamiduddin and Daseking, 2014) that will not be passed onto subsequent purchasers, who pay the full market value. A significant shift towards a more affluent and older population - effectively a gentrification process - reported elsewhere (Tummers 2015) would inevitably reduce both the available pool of workers for manufacturing or productive industries and the recent graduates for the smaller knowledge-based start-ups that currently characterise the Loretto and French quarters.

With respect to employee travel patterns, the data showed pronounced differences in commuting patterns by distance and modal share between the short distance neighbourhoods and the control neighbourhoods, even though levels of car ownership were similar across each of the data subsets. Across all employees of the short distance cluster 37\% used their car to commute compared with 54\% in the control cluster. However when focusing on employees who both live and work in each of the clusters more pronounced differences emerged with only $7 \%$ of residents living within the short distance cluster travelled to work by car, compared with $35 \%$ in the control. Similarly $49 \%$ of respondents walked or cycled to work in the short distance neighbourhoods, compared to $25 \%$ in the control. These patterns substantiate overall patterns of transport modal share (Walter, 2011). However, the data also found that the car-reduction measures implemented as part of the design of the Loretto and French Quarters caused dissatisfaction and perhaps some difficulty for those commuting into these quarters from the wider travel to work region by car. Given Tübingen's small size, it is likely that a proportion of employees in many organisations would need to be drawn from the wider region, for many of whom the automobile would be the only viable commute option. Although the matter wasn't probed in detail, several interviewees indicated that businesses had similar access problems for visitors from the outside of the city. At the time of writing plans had been developed to improve rail connections between Tübingen city and the wider Neckar-Alb region to reduce car-based 
commuting into the city. This would probably improve access to Loretto and French Quarter in turn, although there are no plans to introduce new public transport connections to the main railway station at the present time.

Regarding the key effects of the short distance model for employers, it would appear that constrained car access can be a problem for some employers, although this may be more a reflection on the design detail of Loretto and the French Quarter with their limited car parking arrangements. On the other hand, important benefits include being able to tap into an often excluded labour market of young parents, carers and others requiring more flexible employment arrangements and easy access between home, workplace and local schools or social facilities. These advantages must be weighed against potential constraints including limited space for physical expansion within the neighbourhood setting and more difficult inward access for employees, suppliers and customers.

Although headline work travel figures from this and other research seems to make a convincing case for short distance planning as a way to coerce more sustainable travel behaviour, there remains two areas of considerable uncertainty. Firstly, the role of residential self-selection as a determinant of travel by preference to the neighbourhood environment or a specific mode of travel is not clear. Similar neighbourhoods in Freiburg indicate significant levels of residential self-selection (Hamiduddin, 2015b) which in turn raises a profound question over the wider appeal of this style of planning, or whether it is destined to remain a niche, appealing to a minority with the consequence of only a very limited contribution to $\mathrm{CO}_{2}$ reduction targets. Secondly, and in relation to the final question of wider social effects for employees living close to the workplace, the research did not show evidence of compensatory travel that would be consistent with travel time budgeting. Indeed, this group indicated that they spent more of their leisure time within their neighbourhood than those not co-located. However, only a limited number of travel indicators were used in this study, and these cannot be used as the basis for generating assumptions about the breadth of lifestyle and livelihood organisation. More detailed research on resident travel patterns is required.

Finally, the City of Short Distances model represented by the modestly sized Loretto and the French Quarter areas provides a relevant planning framework for a wide range of settlement scales and situations. It should be remembered that these mixed-use and low car quarters have been achieved on the periphery of a small city with an otherwise centralised urban structure, and that does not have the high quality light rail transit system that other better known sustainable models such as Freiburg's Vauban or Stockholm's Hammarby Sjostad have been planned around (Hall, 2014). Tübingen's compact city quarters therefore illustrate that it is possible to apply an ambitious planning model to sites that would often otherwise be given to lower density mono-functional housing development. It also provides a relevant and interesting model for smallto-medium sized cities. 


\section{Acknowledgements}

The author would like to thank Mr Andreas Feldtkeller for his comments on this research, Ms Miriam Plesker and Mr Max Böhm of the Bergische Universität, Wuppertal for their assistance with data collection, and to the anonymous reviewers who helped to strengthen this paper.

\section{References}

Banister, D. (2005). Unsustainable transport: city transport in the new century. Taylor \& Francis.

Betz, F. (2011) Baugemeinschaften: Experiences from Tübingen, South West Germany. Unpublished presentation available at: www.hallbarastader.gov.se/Bazment/Alias/Files/?fab

Bohte, W., Maat, K., \& van Wee, B. (2009). Measuring attitudes in research on residential self-selection and travel behaviour: a review of theories and empirical research. Transport reviews, 29(3), 325-357.

Buehler, R., \& Pucher, J. (2011). Sustainable transport in Freiburg: lessons from Germany's environmental capital. International Journal of Sustainable Transportation, 5(1), 43-70.

Cao, X., Mokhtarian, P. L., \& Handy, S. L. (2009). Examining the impacts of residential self-selection on travel behaviour: a focus on empirical findings. Transport reviews, 29(3), 359-395.

Chevalier, A., \& Viitanen, T. K. (2002). The causality between female labour force participation and the availability of childcare. Applied economics letters, 9(14), 915- 918.

City of Tübingen (2012a) Municipality-led development with extensive user participation: the Tübingen development strategy by private building cooperatives. Unpublished presentation.

City of Tübingen (2012b) Population by age and municipality on 31.12.2012 [Bevölkerung nach Altersjahren und Stadtteilen am 31.12.2012]

City of Tübingen (2013) Overview of French Quarter / Loretto, available at: http://www.tuebingen.de/loretto\#1608 (accessed 08 Oct 13)

City of Tübingen (1993) Südstadt Rahmenplan [masterplan]. Unpublished document.

EPA - US Environmental Protection Agency (2016) Global Greenhouse Emissions. Available at: https://www3.epa.gov/climatechange/ghgemissions/global.html [accessed 22nd May 2016]

European Commission (2016) Reducing Emissions from Transport. Available at: 
http://ec.europa.eu/clima/policies/transport/index_en.htm [accessed 23rd May 2016]

Feldtkeller, A. (2015) Zwischen Planung und Selbstregelung. [Between Planning and Self- Regulation] In: Scharf, A. \& Gütschow (Eds) Französisches Viertel, Tübingen. Stadtwandel, Regensburg.

Feldtkeller, A. (2012). Zur Alltagstauglichkeit Unserer Städte. Schiller, Tübingen.

Feldtkeller, A. (2001). Städtebau: Vielfalt und Integration. Deutsche Verlags-Anstalt.

Galbraith, C. S. (1985). High-technology location and development: the case of Orange County. California Management Review, 28(1), 98-109.

Hamiduddin, I. (2015a). Social sustainability, residential design and demographic balance: neighbourhood planning strategies in Freiburg, Germany. The Town Planning Review, 86(1), 29-52.

Hamiduddin, I. (2015b) The Car in the Neighbourhood: Residential Design and Social Outcomes in Southern Germany. In Hickman, R. Bonia, M. \& Banister, D. (Eds) Handbook of Transport. Edward Elgar, Cheltenham.

Hamiduddin, I., \& Daseking, W. (2014). Community-based planning in Freiburg, Germany: the case of Vauban. In: Gallent, N. and Ciaffi (Eds) Community Action and Planning. Policy Press, Bristol.

Holden, E., \& Linnerud, K. (2011). Troublesome leisure travel: The contradictions of three sustainable transport policies. Urban studies, 48 (14), 3087 - 3106.

Hall, P. (2014) Good Cities, Better Lives: how Europe rediscovered the lost art of urbanism. Routledge, Abingdon

Hekman, J. S. (1982). Survey of location decisions in the south. Economic Review, 6, 6-19.

Houghton, J.T., Jenkins, G.J. and Ephraums, J.J. (1990) Climate Change: The IPCC Scientific Assessment. Cambridge University Press, Cambridge.

Howley, P., Scott, M., \& Redmond, D. (2009). Sustainability versus liveability: an investigation of neighbourhood satisfaction. Journal of environmental planning and management, 52(6), 847-864.

Jacobs, J. (1990). The death and life of great American cities. Vintage. New York.

Mees, P. (2010). Transport for suburbia: beyond the automobile age. Earthscan, London.

Melia, S., Parkhurst, G., \& Barton, H. (2011). The paradox of intensification. Transport Policy, 18(1), 4652. 
Metz, D. (2008). The myth of travel time saving. Transport Reviews, 28(3), 321-336. 40

Newman, P. W., \& Kenworthy, J. R. (1989). Gasoline consumption and cities: a comparison of US cities with a global survey. Journal of the American Planning Association, 55(1), 24-37.

Mokhtarian, P. L., \& Chen, C. (2004). TTB or not TTB, that is the question: a review and analysis of the empirical literature on travel time (and money) budgets. Transportation Research Part A: Policy and Practice, 38(9), 643-675.

Neuman, M. (2005). The compact city fallacy. Journal of planning education and research, 25(1), 11-26.

Pachauri, R. K. , Allen, M. R. , Barros, V. R., Broome, J., Cramer, W. , Christ, R. , Church, J. A. , Clarke, L., Dahe, Q., Dasgupta, P. , Dubash, N. K., Edenhofer, O., Elgizouli, I. , Field, C. B. , Forster, P. , Friedlingstein, P. , Fuglestvedt, J. , Gomez-Echeverri, L. , Hallegatte, S. , Hegerl, G. , Howden, M. , Jiang, K. , Jimenez Cisneroz, B. , Kattsov, V. , Lee, H. , Mach, K. J. , Marotzke, J. , Mastrandrea, M. D. , Meyer, L. , Minx, J. , Mulugetta, Y. , O'Brien, K. , Oppenheimer, M. , Pereira, J. J. , PichsMadruga, R., Plattner, G. K. , Pörtner, H. O. , Power, S. B. , Preston, B., Ravindranath, N. H. , Reisinger, A. , Riahi, K. , Rusticucci, M. , Scholes, R. , Seyboth, K. , Sokona, Y., 1 Stavins, R. , Stocker, T. F. , Tschakert, P. , van Vuuren, D. and van Ypserle, J. P. (2014): Climate Change 2014: Synthesis Report. Contribution of Working Groups I, II and III to the Fifth Assessment Report of the Intergovernmental Panel on Climate Change / R. Pachauri and L. Meyer (editors), Geneva, Switzerland, IPCC, 151 p., ISBN: 978-92-9169-143-2

Tummers, L. (2015). Understanding co-housing from a planning perspective: why and how?. Urban Research \& Practice, 8(1), 64-78.

Walker, E., \& Brown, A. (2004). What success factors are important to small business owners? International small business journal, 22(6), 577-594.

Walter, S. (2011) Potenzialabschätzung für ein autofreies Quartier in Wein. [The potential for a car-free quarter in Vienna] Unpublished presentation, TU Wien. Available at: http://www.architekturwettbewerb.at/data/media/med_binary/original/1303899001.pdf

Wegener, M. (1994) Die Stadt der kurzen Wege - müssen wir unsere Städte umbauen [The city of short distances - we have to rebuild our cities] Faculty of Urban Planning Working Paper 136, University of Dortmund. 